\title{
ДИГИТАЛНЕ СПЕЦИЈАЛНЕ БИБЛИОТЕКЕ НАУЧНОИСТРАЖИВАЧКИХ ИНСТИТУТА И ЊИХОВО УКЉУЧИВАЊЕ У САВРЕМЕНЕ ИНФОРМАЦИОНЕ ТОКОВЕ
}

\author{
Сажетак
}

\begin{abstract}
Дигиталне специјалне библиотеке воде ка побољшању библиотечких услуга и сервиса, и омогућавају приступ различитим типовима информација. Дигиталне библиотеке представљају саму суштину електронских библиотека, где се комбинацијом рада на дигитализацији и једноставног и брзог приступа информацијама од стране корисника остварују предуслови за укључивање специјалних библиотека научноистраживачких института у савремене информационе токове. У оквиру специјалних библиотека као важних информационих центара, коришћењем библиотечких ресурса, врши се повезивање штампаних и електронских извора. Информациона писменост омогућава да уз помоћ вештина одредимо када су нам информације потребне и где можемо да их нађемо брзо и ефикасно. Информациона писменост обухвата читав скуп вештина као што су: библиотечке вештине, компјутерска писменост, информационо-технолошка писменост, информационе вештине и начини учења. Аутоматизовани библиотечко-информациони систем једне земље је инфраструктурни основ развоја науке. Потенцијали библиотечко-информационог система још увек нису довољно искоришћени ни у библиотекарској, ни у истраживачкој заједници. Кључни однос који треба научно истражити и вредновати јесте однос библиотечкоинформационог система и система научних информација.
\end{abstract}

Кључне речи: дигитална библиотека, специјалне библиотеке, научноистраживачки институти, информациона писменост

\section{Специјалне библиотеке научноистраживачких института у Србији у окружењу дигитализације}

Сврха стварања дигиталних збирки је заштита оригиналних материјала, омогућавање претраживања, олакшавање и ширење јавног приступа да би се помогло корисницима да унапреде знање. 
Дигиталне библиотеке представљају саму суштину електронских библиотека, где се комбинацијом рада на дигитализацији и једноставног и брзог приступа информацијама од стране корисника остварују предуслови за укључивање специјалних библиотека научноистраживачких института у савремене информационе токове.

Поред трансформације у дигиталне библиотеке, специјалне библиотеке, као и библиотеке уопште, треба да покажу да и даље постоје разлози за њихово постојање, јер оне представљају место где корисници траже потребне информације и публикације, било да су у питању штампане публикације или информације доступне преко Интернета.У великим светским библиотекама све више се ради на изради портала, који се постављају на њихове веб странице. Портали у ствари представљају неку врсту класификационе шеме са подацима о важним Интернет адресама за поједине научне и стручне области или поједине специфичне теме, значајне за кориснике којима су намењени. Портали могу бити општи или уско стручни, резулатат рада једне библиотеке или заједница библиотека или неког стручног удружења и сл. Суштина је у томе да знатно олакшавају проналажење релевантних сајтова на Интернету, а самим тим и релевантних садржаја у електронском облику.

\section{Информациона писменост}

Информациона писменост омогућава да уз помоћ вештина одредимо када су нам информације потребне и где можемо да их нађемо брзо и ефикасно. Информациона писменост обухвата читав скуп вештина као што су: библиотечке вештине, компјутерска писменост, информационо-технолошка писменост, информационе вештине и начини учења. Нова улога библиотекара захтева измене у приступу образовања библиотечко-информационих стручњака. У данашњем добу корисник има могућност самосталног приступа удаљеним базама података, тако да је улога библиотекара углавном неопходна код обављања сложених претраживања и избора пронађених података.

Библиотекари у специјалним библиотекама треба да обезбеде слободан приступ информацијама, да имају актуелне фондове и 
савремену опрему како би задовољили потребе својих корисника. Библиотекари у специјалним библиотекама треба да врше тематска и аналитичка претраживања, асистирају у претраживању база података, електронског каталога и интернета, дају инструкције корисницима у раду на рачунарима, упутства за претраживање интернета и преузимање података у свим форматима.

\section{Библиотечко-информациони систем специјалних библиотека}

Како се процеси знања брзо развијају и како дигитално знање све више преовладава, долазимо до тога да основне послове у специјалним библиотекама научноистраживачких института, а и другим типовима библиотека, треба прилагодити новом времену. Морамо бити свесни нових потреба корисника и прилагодити се њима.

Умрежавање библиотека, односно библиотечка мрежа је битна карактеристика специјалних библиотека. Целокупни фонд неких специјалних библиотека може да буде намењен мрежи библиотека, односно корисницима умрежених библиотека. Библиотечко-информациони систем специјалних библиотека је важан из више разлога:

- преко Интернета се омогућава много боља комуникација са сарадницима, колегама и корисницима,

- могућ је приступ информацијама којих нема на другом месту,

- информације се брзо проналазе,

- међубиблиотечка позајмица се остварује на много бржи начин.

Данас се осећа потреба за библиотечко-информационом мрежом специјалних библиотека, нарочито због важности и актуелности умрежених информација. Ако су у питању специјалне библиотеке научноистраживачких института, онда библиотечко - информациони систем тих специјалних библиотека највише зависи од одлука и политике коју воде матичне организације у чијем саставу се налазе специјалне библиотеке. Најважније је да се схвати вредност информационих система за одређену установу. У таквим ситуацијама, библиотекари специјалних библиотека морају да одиграју кључну улогу у трансформисању билиотечког пословања. Можемо да закључимо да даљи развој специјалних 
библиотека зависи од постојања библиотечко - информационих система. Аутоматизовани библиотечко-информациони систем једне земље је инфраструктурни основ развоја науке. Потенцијали библиотечкоинформационог система још увек нису довољно искоришћени ни у библиотекарској, ни у истраживачкој заједници. Кључни однос који треба научно истражити и вредновати јесте однос библиотечко-информационог система и система научних информација.

\section{Специјална библиотека Института за путеве АД Београд}

Библиотека Института за путеве АД, Београд основана је 30.09.1985. године. Представља специјалну библиотеку у саставу Института. Њена примарна улога је да задовољава потребе научноистраживачког, стручног и пројектног рада, уз поштовање начела библиотечко-информационе делатности. Библиотека обезбеђује подршку научноистраживачком и стручном раду, системски прикупља, стручно обрађује, чува, похрањује и даје на коришћење библиотечку грађу и информације неопходне за одвијање и унапређење истраживачког и стручног рада Института.

Библиотека располаже основним фондом домаћих и страних монографских публикација и серијских публикација које обрађују питања из области: планирања, пројектовања, изградње, одржавања, заштите, експлоатације путева, градских саобраћајница и аеродромских писта, као и сродних дисциплина. Фонд чини и репрезентативна грађа из области: геотехнике, испитивања грађевинских материјала, технологије грађења, урбанизма, просторног планирања, екологије, очувања животне средине, система квалитета и састоји се од 5000 библиотечких јединица монографских публикација. Библиотека поседује и збирку референтних публикација (речника, енциклопедија и др.), као и збирку магистарских и докторских дисертација сарадника Института.

Током година, Библиотека је перманентно обнављала свој фонд новим актуелним издањима из области свих грана грађевинарства, технике, заштите животне средине, технолошког инжењеринга, информатике, и слично. Мисија Библиотеке је да обнавља и проширује 
свој фонд не само куповином, већ и разменом, поклонима, као и сарадњом са другим научним и образованим институцијама на регионалном и међународном нивоу.

Поред обраде књига и часописа, посебна пажња се посвећује изради библиографија стручних радова истраживача Института. У библиографијама се поред описа библиографске јединице, у напоменама детаљно образлаже о чему аутори говоре у научно-стручним радовима.

Библиотечко пословање Библиотеке Института за путеве АД Београд је аутоматизовано. Библиотека Института је укључена у Заједницу библиотека Универзитета у Београду, коју поред Универзитетске библиотеке „Светозар Марковић“ и факултетских библиотека, чине и библиотеке у саставу научних института удружених у Универзитет у Београду, са којима је такође током година остваривана успешна сарадња. Библиотека остварује блиску сарадњу са већином сличних библиотека, а посебно са Универзитетском библиотеком „Светозар Марковић“ (UBSM) у Београду, која је и матична библиотека Библиотеци Института за путеве АД, Београд. Библиотека за своје кориснике има слободан приступ целокупном фонду UBSM на основу колективног чланства које се обнавља на годишњем нивоу. Преко система SUBITO, такође при UBSM, редовно остварујемо међубиблиотечку позајмицу књига и часописа са иностранством за наше истраживаче. Веома блиску сарадњу Библиотека има и са Одељењем за научне информације Народне библиотеке Србије. Тачније, преко Конзорцијума библиотека Србије за обједињену набавку (KOBSON) доступно нам је 35000 наслова научних и стручних међународних часописа у електронском облику, као и 90000 књига у пуном тексту (System Ebrary). Већина истраживача Института има лозинке за приступ овим сервисима и за рад од куће. Приступ овом порталу не тражи никакве посебне дозволе осим што се подразумева да ће се придржавати правила коришћења истакнута на њиховој интернет страни.

\section{Перспектива специјалних библиотека}

Будућност специјалних библиотека зависи од односа матичних установа у чијем окриљу постоје. Начин рада библиотекара са корис- 
ницима, као и слика коју о себи креирају може да буде пресудна за однос руководства установе према специјалној библиотеци, посебно у домену финансирања набавке опреме и библиотечке грађе.

Неопходно је да опстану неке форме удруживања које утичу на интезитет и квалитет претраживања база података као што је КОБСОН. Библиотекари постају драгоцена помоћ научним и истраживачким радницима тако што врше обуку истраживача, подучавајући их основним техникама приликом претраживања електронских извора. Развој истраживања одређене научне дисциплине је свакодневан, а актуелне базе података и отворен приступ су драгоцен извор истраживања. Перспектива развоја специјалних библиотека у врмену дигитализације подразумева: стратегију професионалне обуке и континуираног образовања библиотечких радника, пројекат етапног повезивања библиотека у јединствен информациони систем, сарадњу са међународним струковним асоцијацијама и удружењима, осавремењивање простора и опреме за библиотеке, израду система контроле и реализације зацртане стратегије.

\section{Литертура}

Ojala, M. (1993). Core competencies for special library managers of the future. Special Libraries. 4, 230-234.

Клејтон, П., Јуџин - Горман, Г. (2003). Управљање изворима информација: управљање фондовима у теорији и пракси. Београд : Clio

Вучковић, Жељко (2008). Информатичка и медијска писменост као предусловразвоја друштва знања. Инфомациона писменост и доживотно учење : Зборник радова. Београд : Филолошки факултет Универзитета : Библиотекарско друштво Србије, 2008. 


\section{Jelena Dobrilović Dragović}

The Highway Institute

\section{DIGITAL SPECIAL LIBRARY SCIENTIFIC RESEARCH INSTITUTES AND THEIR INTEGRATION INTO THE MODERN INFORMATION FLOWS}

\section{Summary}

Digital special library lead to the improvement of library services and services, and allow access to different types of information. Digital libraries are the very essence of the electronic library, where the combination of work on digitalization and easy and fast access to information by the user achieve the preconditions for the inclusion of special libraries of scientific research institutes in the modern information flows. Within the framework of special libraries as important centers of information, using library resources, for connection of printed and electronic resources. Information literacy enables you with the skills determine when the information we need and where we can find them quickly and efficiently. Information literacy involves a whole set of skills such as library skills, computer literacy, information-technology literacy, information skills and learning styles. The automated library and information system of one country's infrastructure basis for the development of science. The potential of the library information system is still not enough used in the library, nor in the research community. The key aspect that has to be scientificaly explored and evaluated is the relation between the libraryinformational system and the scientific and tehnological information system.

Key words: digital library, special libraries, scientific research institutes, information literacy 